\title{
Exploring the Antecedents of Different Dimensions of Intrapreneurship: The Case of Pakistani Software Industry in Islamic Perspective
}

\author{
Usman Javed ${ }^{1}$, Muhammad Mavia ${ }^{2}$, Aamer Shareef ${ }^{3 *}$, Syed Hassan Jamil ${ }^{4}$ \\ 1,2 Department of Management Sciences, COMSATS University, Lahore Campus, Pakistan \\ ${ }^{3,4}$ Faculty of Management Sciences, Riphah International University, Islamabad, Pakistan
}

\section{Keywords}

Spiritual Leadership

Risk-Taking

Proactiveness

Innovativeness

Software Industry

Received: 23 September 2020

Accepted: 20 November 2020

\begin{abstract}
.
Purpose: Given the lack of research on the dimensions of employees' intrapreneurial behaviour, the current research speculates on the effect of spiritual leadership on three dimensions of employees' intrapreneurialproactiveness, risk-taking, and innovativeness. The study also proposes psychological empowerment as a mediator of these links of spiritual leadership and the dimensions of intrapreneurship.

Methodology: Survey data collected using a time-lagged strategy from 169 software developers working in Pakistan revealed that spiritual leadership positively influences all three dimensions of intrapreneurship. Likewise, psychological empowerment mediates spiritual leadership-proactiveness.

Findings: Interestingly, the results revealed that psychological empowerment did not mediate the association of spiritual leadership with risk-taking and the association of spiritual leadership with innovativeness. Thus, we concluded that the dimensions of intrapreneurship can have different nomological networks of predictors and consequences.

Significance: For theoretical contribution, this effect is important to study because intrinsic motivation (through psychological empowerment) can be an important predictor for intrapreneurship behaviour.

Practical Implications: The study provides managers with important practical implications.
\end{abstract}

KAUJIE Classification: T5, P2

JEL Classification: L08, L26

\section{INTRODUCTION}

Dynamic and revolutionary business practices have made organizations' sustainability quite difficult (Tajeddini et al., 2020). The competitive arena of business practices is also putting pressure on organizations to keep intact in competition. For organizations to avoid vulnerability; innovation, proactive approach, and taking the calculative risk, intrapreneurship (Covin \&

${ }^{*}$ Corresponding author: Aamer Shareef

†Email: aamer.shareef@riphah.edu.pk; ORCID: https://orcid.org/0000-0003-2910-5669 
Slevin, 1991; Gawke et al., 2017; Lumpkin \& Dess, 1996), is of utmost importance. Considerable evidence suggests that employee intrapreneurship behaviour can fundamentally help organizations to remain competitive and perform well (Rauch et al., 2009). Intrapreneurship refers to involving one or all the behaviours such as; innovativeness, proactiveness, and risk-taking (Stull \& Singh, 2005). For intrapreneurship to occur in organizations, leaders and managers need to encourage and support, as individuals require support for innovativeness, proactiveness, and risk-taking, as leaders are the individuals with the knowledge to manage people and get the desired outcomes (Lean, 2012). Although, prior research has investigated the relationship between leadership and intrapreneurship (Moriano et al., 2014), and this empirical investigation has largely focused on leader and manager support in enhancing intrapreneurship behaviour. This prior study investigated the formal leader-follower relationship that provided directional influence. In theorizing this research, we focused on spiritual leadership. Because, spiritual leadership is less leader-centric and focuses on the collective social process to enhance organizational performance (Day, 2000). Thus, spiritual leadership engages everyone in the organization to perform their tasks in meaningful ways without imposing a formal leader-follower relationship. Since the leadership has obvious positive work-related outcomes, so the field of leadership demands more inquiry. Emerging trends in the field of leadership have taken it towards value-based leadership (Chen \& Li, 2013). This is in comparison with traditional leadership roles and models, based on economic cost and benefits fundamentals, dealing with role exchange, providing direction, setting goals, and reinforcement behaviour (Bass, 1985). As far as the value-based perspective of leadership is concerned, this new-genre of leadership has focused on leaders' behaviours based on, vision, ideology, inspiration, and intellectual stimulation (Avolio et al., 2009). Spiritual leadership has emerged as a value-based perspective of leadership and is recognized as a new area of inquiry (Avolio et al., 2009).

Spiritual leadership theory focuses on the well-being of both the leaders and followers, which ultimately helps organizational performance. Spiritual leadership theory involves leaders to develop a vision, inculcating a sense of faith and hope for the accomplishment of vision, and developing an overall culture of love and care (Fry, 2005, 2008). This, consequently, inspires the followers to follow the path laid by the leader. Moreover, spiritual leadership taps the need for the well-being, of leaders and followers, by providing a sense of membership and calling. This, in turn, drives leaders and followers to accomplish the organizational vision and the overall performance is enhanced (Fry, 2003, 2005, 2008). In developing a theoretical model linking spiritual leadership and intrapreneurship behaviour, we further proposed a mediating mechanism showing high potential to explain the relationship between spiritual leadership and intrapreneurship: psychological empowerment. This mediating mechanism, psychological empowerment, is defined by Spreitzer (1995) as a psychological condition that is manifested in four cognitive states: meaningfulness, felt competence, self-determination, and impact. Thus, we explored the extent to which spiritual leadership mediates through psychological empowerment to eventually influence intrapreneurship behaviour.

Drawing upon the theory of spiritual leadership and Islamic religious values, the transformation of various tenets of spiritual leadership into Islamic leadership may be more valuable 
by the firms employing Muslim workers (Egel \& Fry, 2017). Toor (2011) denotes Islamic leadership, or leadership from an Islamic perspective (LIP), as "a social process in which the leader seeks to achieve certain organizational goals by garnering the support from relevant stakeholders-primarily followers-while fully complying to Islamic teachings and principles." While devising the guidelines for Islamic leaders, Islamic leadership posits that material and spiritual pursuits can be separated, thereby the action of Islamic leaders should comply with Islamic values (Mahmood, 2006). As The Holy Qur'ān states: "God hath permitted trade" (Qur'ān 2:275). The trading activities that contribute towards the growth of economy and wellbeing of society can shape the status of worship if these are performed by following Islamic ethical conduct.

Prior research has suggested that empowerment makes an important relationship with creativity, innovation, and proactiveness- such as entrepreneurship - by affecting individuals' intrinsic motivation (Amabile, 1996; Spreitzer, 1996), but the empirical side of the given effect is lacking (Shalley et al., 2004). For theoretical contribution, this effect is important to study because intrinsic motivation (through psychological empowerment) can be an important predictor for intrapreneurship behaviour. We posit that psychological empowerment boosts the intrinsic motivation to perform difficult tasks, such as innovation, proactiveness, and risk-taking (intrapreneurship). Since intrapreneurship is attributed to obvious benefits for organizations, so the positive effects of intrapreneurship are more profound in the software industry.

The software (IT) industry is attributed to rapidly changing technology, a shortened product life cycle, and a higher rate of new product development. The software industry in Pakistan is flourishing rapidly with more than 2500 registered IT companies in Pakistan having \$2.8 billion annual exports (TechJuice, 2015). In such a case, intrapreneurship behaviour can help the software industry to respond to the competitive pressure and sustaining growth at the same time. The model of this study has been contextualized in Pakistan, because for the following three major reasons. First, Pakistan is a Muslim-majority country, and spirituality is one of the dominant concepts of the Qur'ānic teachings. The Qur'ān highlights the importance of spiritual values through several verses. Working for the welfare of others is one of the most important aspects of a Muslim's faith. The following verse illuminates this concept as under: "And when the prayer is ended, then disperse in the land and seek of Allah's favor, and remember Allah much, that you may succeed" (Qur'ān 62:10). Likewise, suppressing anger, forgiving others, and fulfilling others' needs that are fundamental features of spiritual leadership has been portrayed as important aspects of faith. Allah swt says:

"Hasten to forgiveness from your Lord and a garden as wide as the heavens and the earth prepared for the righteous, those who spend in charity at times of ease and difficulty, who suppress their anger and pardon people, for Allah loves those who are excellent" (the Qur'ān, 3:134).

Islam has even stressed to do good with those who are evil to you. The following Hadith describes such a concept of character as follows: "Verily, excellence is that you are good to those who are evil to you, not merely that you are good only to those who are good to you" 
(Tafseer Ibn Kathir 29:69). Islam has also emphasized the importance of entrepreneurial behaviours for human life. For instance, the Prophet Muhammad (peace be upon him) was asked what type of earning was best, and he replied: "A man's work with his hands and every (lawful) business transaction." (Al Tirmidhi). However, despite the emphasis of Islam on both spiritual values and entrepreneurship, little is known about the role of leadership in association with entrepreneurship or intrapreneurship.

Our research carries multiple theoretical contributions and several practical implications. Spiritual leadership literature does not explain how managers can address the issue of intrapreneurship behaviour. Moriano et al. (2014) studied the relationship between transformational leadership and intrapreneurship behaviour; however, they treated intrapreneurship behaviour as a unitary construct that does not explicate the complexities involved in intrapreneurship behaviour. Consequently, Moriano et al. (2014) did not explain how different facets of intrapreneurship behaviours are created. According to Stull and Singh (2005), intrapreneurship is employees' behaviour at multiple levels of an organization performing one or more facets of intrapreneurship (innovation, proactiveness, and risk-taking). Although these facets are highly correlated, they can have different networks of predictors and outcomes (Stull and Singh, 2005). Thus, we extended the prior research by treating intrapreneurship behaviour as the multi (three) dimensional construct. By showing the positive relationship of spiritual leadership with different facets of intrapreneurship behaviour, our research brings to the fore the importance of understanding the different intrapreneurship behaviours and suggests the leadership role as to how they encourage different positive behaviours. In doing so, this study makes important contributions to the spiritual leadership and employees' intrapreneurship's existing literature. Moreover, our study adds value to the literature of spiritual leadership theory by following the mechanism of the original theory of Fry (2003). In the spiritual leadership theory (Fry 2003) explicates the leader develops vision, hope/faith to achieve the vision, and altruistic love for self and others that positively affect psychological empowerment, which ultimately positively influences intrapreneurship. Importantly, our research adds another key contribution to the literature, which is the mediatory role of psychological empowerment in the relationship between spiritual leadership and intrapreneurship behaviour (see Figure 1 for the proposed model). The mediating mechanism explains that why spiritual leadership affects positively different dimensions of employees' intrapreneurship. This way, this study demonstrated that spiritual leader can help employees by empowering them psychologically, which in turn motivate them to develop/engage in intrapreneurship.

\section{LITERATURE REVIEW}

\section{Spiritual Leadership and Innovativeness}

Intrapreneurship is considered as a key element for organizational success in economic terms (Antoncic \& Hisrich, 2001). Due to the important consequences of intrapreneurship such as organizational performance and organizational revitalization, scholars have expressed their interest in this construct (Burgelman, 1983; Kanter, 1984). Intrapreneurship has equal importance for large and small-medium organizations (Antoncic \& Hisrich, 2001). 
Intrapreneurship can be defined as "..increased consensus has been attained on the concept of entrepreneurship as the process of uncovering and developing an opportunity to create value through innovation and seizing that opportunity without regard to either resource (human and capital) or the location of the entrepreneur - in a new or existing company" (Churchill, 1992). Innovativeness encompasses the degree of an individual's inclination towards a new activity that has likely higher chances to result in improved processes, products, and services (Moriano et al., 2014). Innovativeness is a self-initiative work behaviour with an individual attempt to think out of the box for improved processes, products, and services. More specifically, intrapreneurs attempt to think outside of the box so that they can come up with unique ideas to improve organizational processes. Thus, Moriano et al. (2014) argued that intrapreneurs act as a driving force for product and services improvement, development, and market penetration as well. Intrapreneurs are individuals characterized by innovative, motivation to succeed, and overcoming those challenges for the sake of personal learning and development (Lumpkin \& Dess, 1996). Globalization has brought numerous challenges to organizations such as those that need to have a diverse and innovative workforce so that it can survive in a dynamic environment (Khan, 2018) and creating value for stakeholders. Additionally, this phenomenon has challenged the leader's capabilities such that they have to mitigate environmental pressures for organizational survival. Latham (2014) has suggested that stakeholders can be satisfied with value-added products and services provided by the organization through innovation in products and services. Thus, it can be argued that an organization that possesses the right workforce with innovative characteristics and encourage innovative ideas have likely higher chances of survival for the long term. Due to the importance of innovation in products and services for organizational survival, Latham (2014) has recommended that leaders have to design different organizational strategies to improve innovativeness. Top and middle-level managers are significant contributors to facilitate intrapreneurship activities in organizational settings (Hornsby et al., 2002; Kuratko et al., 2005). Kuratko et al. (2005) argued that managers act as a driving force to initiate intrapreneurial activities in numerous ways such that they provide necessary resources and support for small projects. Leaders have the ability to lead their subordinates towards goal achievement such that every leader has the vision to achieve specific goals by demonstrating future state that have mutual benefits for the organization and for employees as well. The spiritual leader sets a vision by demonstrating possible working methods with which set goals can be achieved and shows care and concern for his subordinates thus shows altruistic love for his followers (Chen \& Li, 2013).

Chen and Li (2013) conducted a research study and claimed that spiritual leaders intrinsically motivate their subordinates through their core characteristics (vision, hope/faith, and altruistic love) and these have a positive influence on organizational performance and organizational citizenship behaviour (Chen \& Li, 2013). Fry et al. (2010) noted that spiritual leadership provides the underlying foundation for developing empowerment, creativity, and innovation. Spiritual leaders attempt to intrinsically motivate subordinates for psychological wellbeing through their core characteristics "altruistic love" with which subordinates attempt to bring innovation for improved organizational processes. Damanpour (1991) conducted a meta-analysis of 46 research studies and demonstrated that managers' attitude towards 
change is a significant predictor of innovation in organizational settings. Based on this meta-analysis, it can be claimed that spiritual leaders' attitudes to cater to environmental challenges contribute to encouraging their subordinates to think out of the box for improved and value-added benefits for products and services. Elenkov et al. (2005) conducted a research study on senior executives from six countries and found that visionary characteristics of leaders have a positive influence on innovation. Spiritual leaders due to their visionary characteristics will have a positive influence on innovation. Jung et al. (2003) in their research study on Taiwanese companies confirmed that a leader characterized by transformational characteristics such as vision and care, concern, and appreciation for others has a significant positive effect on innovation. Therefore, it is evident to claim that managers who are rated high on spiritual leadership characteristics have likely higher chances to engage their followers in intrapreneurial activities such as extra work, work innovation (Howell \& Higgins, 1990; Jung et al., 2003; Koh et al., 1995; Podsakoff et al., 1990).

Spiritual leaders actually serve as an underlying foundation for initiating innovativeness with which intrapreneurial activities are promoted in the organization. Initially, spiritual leaders set a clear organizational vision along with systematic working procedures in pursuit of organizational vision and other opportunities meanwhile (Eyal \& Kark, 2004; Mumford et al., 2002). Moreover, leaders encourage their subordinates to think differently with their own capability to bring innovative ideas that go beyond organizational goals and objectives (Jung et al., 2003). Such encouragement and support to followers help them to think out of the box which questions existing/conventional organizational rules and procedures; thus, it enhances the follower's innovation at the workplace. Additionally, spiritual leaders hope/faith characteristics contribute to increase their confidence in their own capabilities due to which they feel more encouraged and confident about their competencies and strive for best work outcomes (Howell \& Higgins, 1990; Jung et al., 2003). Based upon the above discussion, it is evident to claim that spiritual leadership has a positive influence on innovativeness.

H1: Spiritual leadership positively influences innovativeness.

\section{Spiritual Leadership and Risk-Taking}

Risk-taking refers to venturing into the areas, without knowing the outcomes (Covin \& Slevin, 1991). Employees who were high on characteristics of risk-taking, open and generosity are considered to think individually and in groups contribute to motivating others (Ancona, 1999). Therefore, such individuals are considered to produce novel ideas that can challenge existing organizational rules and procedures. Extensive research has shown that if employees will be provided with committed leaders and empowerment at a team and personal level, they continuously strive to improve and innovate (Ancona, 1999; Bass, 2000; McGill et al., 1992). Therefore, it has highlighted and established the importance of leadership for risk-taking and innovation in organizational settings.

Strategic leaders support autonomy, individual initiative, creativity, and risk-taking (Fry, 2003). Spiritual leadership utilizes the spiritual characteristics of a leader to encourage followers to be risk-takers for intrapreneurial activities. Firstly, when followers perceive that their leader is supportive, trust is built between the leader and his followers (Tierney et al., 
1999). This trust gives hope and faith to both leader and his followers due to which employees feel more empowered and have faith in their capabilities thus proceed confidently in pursuit of projects with unknown outcomes and related risk. In the same vein, Fry et al. (2005) argued that leaders who encourage their followers and groups by demonstrating safe and continuous support, the followers feel more encouraged to take risks for unknown outcomes. Therefore, it is evident to claim that continuous support and faith in followers' capability creates hope and faith between the spiritual leader and his/her followers have a positive influence on the risk-taking propensity of employees. Based upon the above discussion, it is hypothesized that spiritual leadership have positive impact on risk taking.

H2: Spiritual leadership positively influences risk-taking.

\section{Spiritual Leadership and Proactiveness}

Proactiveness refers to the extent to which an individual act in future anticipated needs, is interested in change, or fascinated with challenges for exploring new opportunities (Lumpkin $\&$ Dess, 1996). Globalization has brought numerous challenges to organizations (Khan, 2018) which require organizations to be prepared for uncertain environmental changes. Therefore, Fry et al. (2005) suggested that organizations should be able to quickly implement relevant strategies to effectively respond to environmental changes thus highlighting the importance of Proactiveness. Consistent with transformational leadership characteristics (Brown \& Trevino, 2006), spiritual leaders have the characteristics of being visionary with which they devise working procedures accordingly to meet the shared organizational vision. Crossman (2010) claims that spiritual leaders are characterized by proactiveness with which they are capable of changing other's view of seeing and doing things simultaneously. Spiritual leaders take personal charge and influence others (followers) in the pursuit of a shared organizational vision (Modaff et al., 2008). Additionally, spiritual leaders are capable of building trust and compassion for work (Hoppe, 2005) which in turn enables them to transmit proactiveness characteristics in his/her followers to cater to dynamic environmental challenges. Spiritual leaders "train, educate and coach followers, provide motivation, involve them in approved networks and then free them from situational constraints that hamper growth/transformation towards full effectiveness" (Depree, 1993). Based on this argument, it can be implied that relationship between spiritual leadership and proactiveness are important contributors to cater for environmental challenges. Based upon the above empirical evidence, it is evident to argue that spiritual leadership has a positive impact on proactiveness.

H3: Spiritual leadership positively influences proactiveness.

\section{A Mediating Role of Psychological Empowerment}

Thomas and Velthouse (1990) presented four facets of task interpretation and evaluation, building on the prior work of Conger and Kanungo (1988), for determining the intrinsic motivation, such as psychological empowerment. These four facets are named as meaning, competence, self-determination, and impact. Similarly, following Spreitzer (1995) we understand psychological empowerment as "...increased intrinsic task motivation manifested in a set of four cognitions reflecting an individual's orientation to his or her work role: compe- 
tence, impact, meaning, and self-determination." Meaning as synonymous with Hackman (1980) refers to the synchronization between an individual's work goals, values, and beliefs. In other words, it is with regard to one's caring about work and task. Competence is derived directly from Bandura's (1982) self-efficacy which is about an individual's belief about skills and capability with regard to the task and work performance. Self-determination as a parallel to choice developed by Thomas and Velthouse (1990), refers to the sense of autonomy of individuals and how they control their behaviour about immediate work. And impact refers to an individual's view and opinion about influencing the work outcomes.

Contemporary research provides obvious positive outcomes, for individuals, teams, and organizations, of psychological empowerment (Forrester, 2000; Mathieu et al., 2006; Wallace et al., 2011). At the individual level, psychological empowerment is positively related to wellbeing, performance, and positive attitudes (Hempel et al., 2012; Spreitzer, 2008; Wagner III, 1994). Since psychological empowerment is attributed to positive outcomes, it is reckoned that approximately $70 \%$ of organizations have implemented and adopted empowerment in some form (e.g., Lawler et al., 2001). Organizations have realized when employees will be given autonomy, decision-making participation, and responsibility sharing, their performance, and positive effect is likely to enhance (Maynard et al., 2012). Our interest, in this research, is to find antecedents and outcomes of psychological empowerment that are beneficial for individual and organization at the same time-spiritual leadership and intrapreneurship behaviour, respectively.

Spiritual leadership has its roots in motivation-based aspects. Moreover, it incorporates religious-based characteristics, such as value, care, religion, and spiritual fundamental- ethical considerations- such as treating all the stakeholders with reasonable care and responsibilityand value-based aspects- such as work-based culture, better interpersonal relations, and meaningfulness (Chen \& Li, 2013). Spiritual leadership offers two mechanisms through which leaders inspire their followers (Chen \& Li, 2013). Firstly, SL focuses on followers' attitude formation towards leaders (Bono \& Judge, 2004; Jung \& Avolio, 2000; Podsakoff et al., 1990) and secondly followers' self-concept (Lord \& Brown, 2001; Shamir, 1990; Sosik, 1998). Spiritual leadership has the potential to predict psychological empowerment in followers. Prior research has found that leadership, by creating meaning, goals/vision, and hope to the followers, as the major mechanism of psychological empowerment (Avey et al., 2008; Bono \& Judge, 2003). Spiritual leadership helps followers to follow a vision with the hope to accomplish the vision by loving and caring for others. It posits that spiritual leadership replenishes individuals' innate motivation of empowerment by providing them a vision and hope for the accomplishment of the vision. Vision, hope, and altruistic love-spiritual leadership-leads individuals towards psychological empowerment-as they feel meaningfulness in work (Chen \& Yang, 2012; Dent et al., 2005; Fry et al., 2011; Markow \& Klenke, 2005). Moreover they feel competent (self-efficacy) enough to achieve the goals (Chen \& $\mathrm{Li}$, 2013), and gain a sense of autonomy when individuals gain love, care and developmental opportunities (Conger \& Kanungo, 1998; Shamir et al., 1993) Finally, individuals feel they can create impact through their work and reciprocating the leader's behaviour (Macneil, 1985; Morrison \& Robinson, 1997; Robinson et al., 1994; Rousseau \& McLean Parks, 1993). 
We argue that psychological empowerment is congruent with an individual's innovativeness, proactiveness, and risk-taking - such as intrapreneurship. Likewise, employees who are psychologically empowered are willing to find an innovative and creative process (Zhang \& Bartol, 2010). Generally, when employees perceive their job as important and meaningful to them, they are likely to spend more time and effort to understand the problems and finding the right solution, and gathering information for the problem in an innovative way (Gilson \& Shalley, 2004; Jabri, 1991). Moreover, competence and self-determination have a positive influence on job execution, which foster employees' idea-generating capability persistently (Deci \& Ryan, 1991; Spreitzer, 1995). An important dimension of psychological empowerment is the impact that also becomes an important predictor of innovation. Further, employees who feel they influence the work outcome will likely be involved in innovation. Moreover, Erturk (2012) and Spreitzer (1995) suggest that empowerment has a substantiated impact on innovation. Since innovation is associated with creativity and new idea generation, individuals high on meaningfulness, autonomy, impact, and self-determination-such as psychological impact- are like to be innovative.

Preliminary research shows that spiritual leaders are better able to instill a sense of positive meaning in their followers. In other words, spiritual leaders are more prone to psychologically empower their subordinates by stretching their capabilities and competence (Bayighomog \& Arasli, 2019). Spiritual leaders strive to develop a sense of calling and membership in their employees (Bayighomog \& Arasli, 2019), which eventually help employees in fulfilling their psychological needs such as autonomy, self-efficacy, etc. (Deci \& Ryan, 2000). Thus, it is evident to argue that a spiritual leader enhances employee's psychological empowerment. Psychological empowerment is characterized by self-perception, feeling responsible, important and competent, which ultimately fuels an individual's innovative capacity. Prior research shows that employees who are psychologically empowered, become more proactive to engage in challenging activities such as challenging existing norms (Fry, 2003; Wang et al., 2019). This way, employees with a sense of psychological empowerment, are more willing to engage in innovative behaviours. This way, we formulate the following hypothesis.

H4(a): Psychological empowerment mediates the relationship between spiritual leadership and an individual's innovativeness.

Proactiveness refers to the extent to which an individual acts in future anticipated needs, is interested in change, or fascinated with challenges for exploring new opportunities (Lumpkin $\&$ Dess, 1996). According to Parker et al. (2006) componential antecedents of proactiveness, cognitive-motivation is one of the most powerful and important predictors of employee proactiveness. The motivation of an individual refers to the extent to which one is interested in a task (meaning), inner-directed (self-determination), and engagement in a task (Utman, 1997). Moreover, Thomas and Velthouse (1990) posited that psychological empowerment itself is intrinsic motivation.

Similarly, prior empirical research (Axtell et al., 2000; Parker, 1998; Parker et al., 1997) demonstrated a significant, positive relationship between autonomy, self-efficacy (competence), and proactiveness. Four distinct, but interrelated, dimensions of psychological empowerment help individuals for proactive behaviour. We theorize that psychological 
empowerment may have an important influence on employee's proactiveness. Specifically, when employees perceive that their abilities can create an impact, they believe in their competence and autonomy in tasks lead them towards future anticipation. Morrison and Phelps (1999) also found that self-efficacy and taking charge of the situation have a positive impact on proactiveness. Moreover, prior research shows that employees characterized by psychological empowerment are more proactive (Fry, 2003; Wang et al., 2019). Therefore, based on empirical evidence and arguments demonstrating the links between psychological empowerment and proactiveness, we propose:

H4(b): Psychological empowerment mediates the relationship between spiritual leadership and an individual's proactiveness.

Risk-taking refers to venturing into the areas, without knowing the outcomes (Covin \& Slevin, 1991). Recent empirical evidence indicates that different facets of psychological empowerment are related to an individual's risk-taking. Perceived self-confidence and competence have shown a positive relationship with an individual's risk-taking (Klein \& Kunda, 1994; Krueger Jr \& Dickson, 1994; Sitkin \& Weingart, 1995). Similarly, Klein and Kunda (1994) found that work and task are positively associated with risk-taking. Moreover, community and group thinking also influences an individual's risk-taking (Sitkin \& Pablo, 1992). Surprisingly, little research attention is given to the intrinsic motivation by fulfilling meaningfulness, competence, self-determination, and impact in risk-taking. Competence affects risk-taking through a perception of controlling the events. Self-determination-autonomyinvolves an individual's independent decision making, so they have the propensity to take the risk. Consequently, mentioned attitudes are conceptually relevant to an individual's risktaking. Moreover, Klein and Kunda (1994) found that individuals' ability to control work and events affects their risk-taking ability. Psychological empowerment provides individuals and teams with control over their work (Conger \& Kanungo, 1988; Spreitzer, 1995; Thomas $\&$ Velthouse, 1990) which eventually encourages them to engage in risk-taking behaviours. In other words, individuals possessing a greater sense of work control from psychological empowerment will eventually develop a propensity for risk-taking. Likewise, employees with a sense of psychological empowerment feel that their work and contributions are important, and thus encourage them to indulge in risk-taking behaviour in pursuit of organizational goals.

H4(c): Psychological empowerment mediates the relationship between spiritual leadership and an individual's risk-taking. 


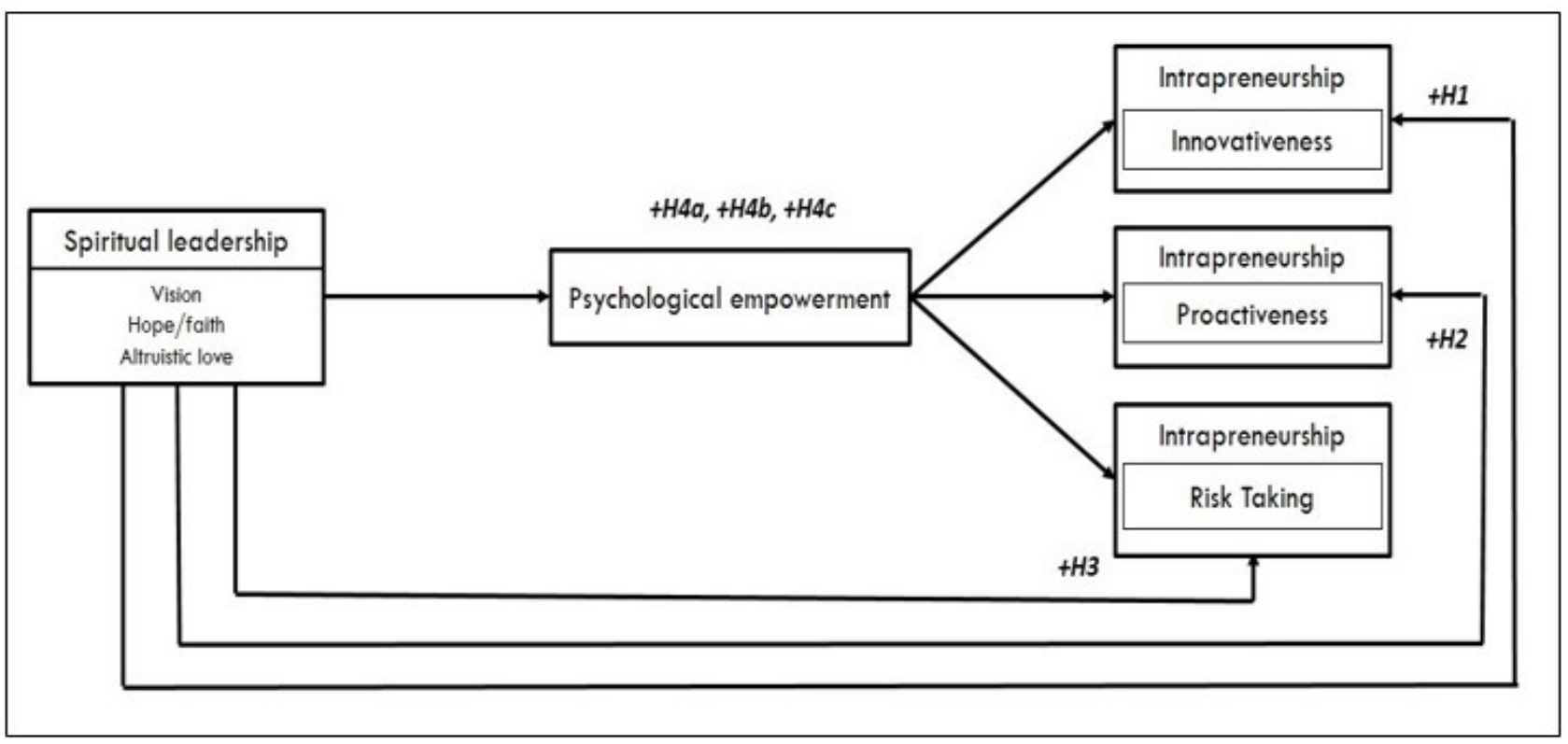

FIGURE 1. Research model

\section{METHODS}

\section{Sample and Data Collection Procedure}

Intrapreneurship refers to the demonstration of entrepreneurial behaviour in an existing firm (Antoncic \& Hisrich, 2001). To capture the maximum variance in intrapreneurship due to spiritual leadership, we selected organizations where management especially leaders support intrapreneurship behaviour such as risk-taking, innovativeness, and proactiveness. We believe that software development firms are continually striving to bring innovative products and services. Therefore, the most suited IT sector especially software development firms were selected in the metropolitan city Lahore, Pakistan. An online questionnaire was developed on the KWIK survey and emailed to managers in three reputed IT firms in Lahore with the author's professional and personal contacts. Managers in IT firms further emailed to their subordinates to fill the online questionnaire by just clicking the web link provided in the email.

At the start of the questionnaire, a brief statement was given to inform respondents about the purpose of this study and to ensure the confidentiality of their valuable responses. The questionnaire was divided into two sections. The first section consists of spiritual leadership and psychological empowerment and the second section consists of intrapreneurship. In time 1 , respondents filled section one and after one month's gap, the same respondents filled the second section of the questionnaire so that they can differentiate between the constructs to minimize the common method bias. Furthermore, respondents also provided their demographic information such as age, gender, email address, and current organization name. We received a total of 200 responses and out of that 31 incomplete questionnaires were excluded from the final sample. The final sample included 169 respondents ( 85 percent response rate).

Since Pakistan's population is male dominant especially at the workplace, the majority 
of the respondents were male with an MS degree. 140 respondents were male and 29 were female. 10 respondents were below 25 years, 88 respondents were between 26 to 30 years old, 50 respondents were between 31 to 35 years old and 21 respondents were above the age of 35 years. 14 respondents were having an intermediate education, 35 were having a bachelor's degree, 53 were having a master's degree and 67 were having an MS degree. 38 respondents were having less than one year of experience, 81 respondents were having 1 to 4 years' experience, 38 respondents were having 5 to 9 years of experience and 12 respondents were having more than 9 years of experience.

\section{Measures}

All responses were measured on a five-point Likert scale ranging from 1=strongly disagree, $2=$ disagree, $3=$ neutral, 4 agree and $5=$ strongly agree.

\section{Spiritual Leadership}

We adapted a 17-items scale from Fry et al. (2005) to measure spiritual leadership. The sample item includes "My manager understands and committed to organizational vision".

\section{Psychological Empowerment}

We adapted a 12-items scale from Spreitzer (1995) to measure psychological empowerment. The sample item includes "The work I do is important to me".

\section{Intrapreneurship}

We adapted a 15-items scale from Stull and Singh (2005) to measure intrapreneurship. The sample item includes "I avoid taking calculated risks".

\section{Control Variables}

We have used the respondent's demographics as control variables because of their possible effect on the outcome variable. Therefore, we have used one-way ANOVA to confirm their effect on the outcome variable. However, one-way ANOVA results revealed that none of the demographics of respondents have any effect on intrapreneurship and therefore these demographics were not controlled in further analysis.

\section{Data Analysis}

Structural equation modeling (SEM) was used to test the mediating effect of psychological empowerment between spiritual leadership and intrapreneurship's three dimensions which are risk-taking, proactiveness, and innovativeness. The proposed theoretical model was executed in warpPLS 6.0 which is based on PLS algorithm. We employed SEM-based PLS algorithm for mediation analysis as PLS algorithm is most suitable for a small sample size (McCormack et al., 2008). First, Confirmatory Factor Analysis (CFA) was performed to confirm the factor loadings so that they can be retained or deleted according to the standard threshold (Hair et al., 2006). Moreover, convergent and discriminant validity is also confirmed by CFA. Importantly, model fit statistics were also confirmed with WarPLS 6.0. SPSS 25th version was used to calculate the demographics of respondents and for descriptive analysis as well.

Model fit was confirmed with the values of average path coefficient (APC), average Rsquared (ARS), and an average of variance inflation factor (AVIF). APC value $(0.227, \mathrm{p}<$ $0.001)$ and ARS value $(0.148, p<0.012)$ were significant thus confirms model fitness and 
model efficiency also (Avelar-Sosa et al., 2015). Additionally, AVIF value (1.008) is less than 3 which also confirms model fitness. After that, convergent validity was confirmed through factor loadings which should be greater than 0.5 (Hair et al., 2012). Two items of innovativeness (INN) were deleted as their factor loading was below 0.5. Moreover, convergent validity is also confirmed through AVE which should be greater than 0.5, and Composite Reliability (CR) which should be greater than 0.7 . Table 1 summarizes the results of convergent validity analysis.

Discriminant validity is confirmed by comparing the square root of Average Variance Extracted (AVE) with corresponding inter variable correlations and a greater value of the square root of AVE confirm discriminant validity (Hair et al., 2006). The results of discriminant validity are presented in Table 2 .

After CFA and validity (convergent and discriminant) satisfactory results, measurement model fitness is confirmed, and therefore, we proceeded further for SEM analysis to test the hypotheses. The results are reported in Table 3 . Results revealed that spiritual leadership (SL) has a significant positive impact on risk-taking $(\beta=0.291, p<0.001)$, proactiveness $(\beta=$ $0.283, p<0.001)$ and innovativeness $(\beta=0.247, p<0.001)$. Thus, the first three hypotheses were confirmed.

The results of the indirect effect of SL on risk-taking, proactiveness, and innovativeness through psychological empowerment (PE) are presented in Table 3. The indirect effect of SL on risk-taking through PE was not significant $(\beta=0.054, p=0.160)$; thus hypothesis 4(a) was not accepted. Similarly, the indirect effect of SL on innovativeness through PE was not significant $(\beta=0.068, p=0.102)$ thus hypothesis $4(b)$ was not accepted. However, the indirect effect of SL on proactiveness through PE was significant $(\beta=0.091, p<0.05)$, and thus hypothesis 4(c) was accepted. 
TABLE 1

Measurement model (convergent validity)

\begin{tabular}{|c|c|c|c|c|}
\hline Construct & Items & Loadings & AVE & CR \\
\hline \multirow[t]{17}{*}{ Spiritual leadership } & SL1 & 0.756 & \multirow[t]{17}{*}{0} & \multirow[t]{17}{*}{0.956} \\
\hline & SL2 & 0.789 & & \\
\hline & SL3 & 0.689 & & \\
\hline & SL4 & 0.761 & & \\
\hline & SL5 & 0.749 & & \\
\hline & SL6 & 0.761 & & \\
\hline & SL7 & 0.788 & & \\
\hline & SL8 & 0.784 & & \\
\hline & SL9 & 0.738 & & \\
\hline & SL10 & 0.806 & & \\
\hline & SL11 & 0.812 & & \\
\hline & SL12 & 0.787 & & \\
\hline & SL13 & 0.792 & & \\
\hline & SL14 & 0.777 & & \\
\hline & SL15 & 0.768 & & \\
\hline & SL16 & 0.766 & & \\
\hline & SL17 & 0.703 & & \\
\hline \multirow[t]{12}{*}{ Psychological empowerment } & PE1 & 0.755 & \multirow[t]{12}{*}{0} & \multirow[t]{12}{*}{0.953} \\
\hline & PE2 & 0.827 & & \\
\hline & PE3 & 0.769 & & \\
\hline & PE4 & 0.849 & & \\
\hline & PE5 & 0.81 & & \\
\hline & PE6 & 0.801 & & \\
\hline & PE7 & 0.844 & & \\
\hline & PE8 & 0.862 & & \\
\hline & PE9 & 0.803 & & \\
\hline & PE10 & 0.823 & & \\
\hline & PE11 & 0.838 & & \\
\hline & PE12 & 0.793 & & \\
\hline \multirow[t]{2}{*}{ Risk-Taking } & RT1 & 0.751 & \multirow[t]{2}{*}{0} & \multirow[t]{2}{*}{0.884} \\
\hline & RT2 & 0.831 & & \\
\hline
\end{tabular}


TABLE 2

Correlation and discriminant validity

\begin{tabular}{llllll}
\hline \hline & SL & PE & RT & PRO & INN \\
\hline SL & $(0.77)$ & & & & \\
PE & 0.20 & $(0.82)$ & & & \\
RT & 0.18 & 0.19 & $(0.83)$ & & \\
PRO & 0.23 & 0.37 & 0.87 & $(0.87)$ & \\
INN & 0.19 & 0.27 & 0.79 & 0.83 & $(0.89)$ \\
\hline
\end{tabular}

Note: Values on the diagonal are the square root of AVE

TABLE 3

Direct and indirect effects

\begin{tabular}{llll}
\hline \hline Hypothesis & $\beta$ & $p$-values & Decision \\
\hline $\mathrm{SL} \rightarrow \mathrm{RT}$ (Direct Effect) & 0.291 & 0.000 & Supported \\
$\mathrm{SL} \rightarrow$ PRO (Direct Effect) & 0.283 & 0.000 & Supported \\
$\mathrm{SL} \rightarrow \mathrm{INN}$ (Direct Effect) & 0.247 & 0.000 & Supported \\
$\mathrm{SL} \rightarrow \mathrm{PE} \rightarrow$ RT (Indirect Effect) & 0.054 & 0.160 & Not Supported \\
$\mathrm{SL} \rightarrow \mathrm{PE} \rightarrow$ PRO (Indirect Effect) & 0.091 & 0.044 & Supported \\
$\mathrm{SL} \rightarrow \mathrm{PE} \rightarrow$ INN (Indirect Effect) & 0.068 & 0.102 & Not Supported \\
\hline \hline
\end{tabular}

Notes; SL = Spiritual Leadership; RT = Risk taking; INN = Innovation;

$\mathrm{PE}=$ Psychological Empowerment

\section{DISCUSSION AND CONCLUSION}

This study established relationships between spiritual leadership and different dimensions of intrapreneurship. Furthermore, our research focused on a potential underlying mechanism, arguing that employees' psychological empowerment would play a mediatory role. This study seeks to contribute to the literature in three important ways. Firstly, we found that spiritual leadership has a significant and positive impact on all three dimensions of intrapreneurship. One of the interesting findings is that spirituality affected the employees' innovativeness less than proactiveness and risk-taking. The possible explanation for the relationship may be that employees with a strong perception of spiritual leadership are ready to take risks and their proactiveness is increased due to the understanding of vision but innovativeness remains on the lower side because employees need more knowledge and skill for innovativeness. In line with this, being Islamic as a religion of entrepreneurship, it encourages innovation, taking risk and pursuit of opportunities (Kayed \& Hassan 2010). The concept of "risk" and the concept of "rizk" are closely related to each other. Muslims have a firm belief that "rizk" is granted by the Allah, hence the entrepreneur should have firm faith "tawwakul" in Allah. In this way, taking the risk has been made easier and risk is "outstored" (Gumusay, 2015). The faith or belief in Allah is basically the foundation of all motivations in Islam (Egel \& Fry, 2017). Moreover, in developing countries, such as Pakistan, the research and development 
budget in the organization is set lower which causes the lack of innovativeness in employees.

Secondly, the study contributes to spiritual leadership and psychological empowerment literature by suggesting that psychological empowerment as a mediator through which spiritual leadership influences intrapreneurship behaviour - risk-taking, proactiveness, and innovativeness. As predicted, psychological empowerment significantly mediated the relationship between spiritual leadership and proactiveness. However, one of the interesting findings in our study reveals that psychological empowerment is not a significant mediator of spiritual leadership with risk-taking and innovativeness. The results do not meet our expectations of the mediating role of psychological empowerment with two of the three outcomes such as innovativeness and risk-taking. Three possible reasons for psychological empowerment not supporting as a mediating mechanism can be understood. Firstly, innovativeness and risk-taking are attributed to skills enhancement. In this case, employees may not be concerned with skill enhancement. Secondly, support from the leaders plays important role in inspiring employees to take risks and innovativeness through psychological empowerment. It is likely that leadership, in this case, could not extend support and a sense of empowerment in a way that can lead to risk-taking and innovativeness. These findings, however, suggest that taking intrapreneurship as a unitary construct is flawed, as these dimensions can have different predictors and can also result in several different outcomes. Glossing over the differential effects of these dimensions can result in flawed managerial interventions and waste organizations' resources and efforts to enhance intrapreneurship. Finally, in a power distance culture like Pakistan, the leader's role in developing the followers' attitude and behaviour is more dominant. Pakistani culture is relatively higher on power distance (Hofstede, 1984), and employees seek to get encouragement from their managers in order to involve in risk-taking and innovative matters. Thus, they may not consider psychological empowerment as an important resource helpful for their engagement in risk-taking and innovativeness.

\section{Limitation and Future Direction}

Even though the study has important theoretical contributions and several practical implications, nevertheless, limitations do exist. Such as we have collected the data from the service industry (i.e., IT sector), therefore to generalize the findings of the present model we encourage upcoming scholars to replicate the study in other sectors and industries (e.g., automobile, banking, education). In addition, we also encourage future researchers to replicate this study on other social groups such as disabled people, who probably may not be intended to engage in intrapreneurial behaviour. Thus, it could be interesting to examine other social groups' responses toward intrapreneurship and to make results more generalizable. Moreover, we have managed within employ time-lagged study design, yet to have a better understanding of causality of relationship, we suggest using time-lagged survey design in future. In a similar vein, the study did not include any boundary condition under which the suggested association between variables might be buffered. Therefore we speculate that the inclusion of boundary condition(s) such as the employees' political skills, the leaders' religiosity, and the organizations' innovative culture would enhance the readers' understanding and give better information to the decision-makers. Finally, to enhance the nomological network of 
antecedents and consequences of intrapreneurship and spiritual leadership, we suggest to include different underpinning variables such as coworker exchanges, thriving for work, and employee resilience.

\section{REFERENCES}

Amabile, T. M. (1996). Creativity in context: The social psychology of creativity. Westview Ancona, D. G. (1999). Managing for the future: Organizational behavior $\mathcal{F}$ processes. Thomson South-Western.

Antoncic, B., \& Hisrich, R. D. (2001). Intrapreneurship: Construct refinement and crosscultural validation. Journal of Business Venturing, 16(5), 495-527.

doi: https://doi.org/10.1016/S0883-9026(99)00054-3

Avelar-Sosa, L., Garcia-Alcaraz, J. L., Vergara-Villegas, O. O., Maldonado-Macias, A. A., \& Alor-Hernandez, G. (2015). Impact of traditional and international logistic policies in supply chain performance. The International Journal of Advanced Manufacturing Technology, 76(5-8), 913-925. doi: https://doi.org/10.1007/s00170-014-6308-3

Avey, J. B., Hughes, L. W., Norman, S. M., \& Luthans, K. W. (2008). Using positivity, transformational leadership and empowerment to combat employee negativity. Leadership $\mathcal{E}$ Organization Development Journal, 29(2), 110-126.

doi: https://doi.org/10.1108/01437730810852470

Avolio, B. J., Walumbwa, F. O., \& Weber, T. J. (2009). Leadership: Current theories, research, and future directions. Annual Review of Psychology, 60, 421-449. doi: https://doi.org/10.1146/annurev.psych.60.110707.163621

Axtell, C. M., Holman, D. J., Unsworth, K. L., Wall, T. D., Waterson, P. E., \& Harrington, E. (2000). Shopfloor innovation: Facilitating the suggestion and implementation of ideas. Journal of Occupational and Organizational Psychology, 73(3), 265-285. doi: https://doi.org/10.1348/096317900167029

Bandura, A. (1982). Self-efficacy mechanism in human agency. American Psychologist, 37(2), 122-147. doi: https://doi.org/10.1037/0003-066X.37.2.122

Bass, B. M. (1985). Leadership and performance beyond expectations. Collier Macmillan.

Bass, B. M. (2000). The future of leadership in learning organizations. Journal of Leadership Studies, 7(3), 18-40. doi: https://doi.org/10.1177/107179190000700302

Bayighomog, S. W., \& Arasli, H. (2019). Workplace spirituality-customer engagement Nexus: The mediated role of spiritual leadership on customer-oriented boundaryspanning behaviors. Service Industries Journal, 39(7-8), 637-661.

doi: https://doi.org/10.1080/02642069.2019.1570153

Bono, J. E., \& Judge, T. A. (2003). Self-concordance at work: Toward understanding the motivational effects of transformational leaders. Academy of Management Journal, 46(5), 554-571. doi: https://doi.org/10.2307/30040649

Bono, J. E., \& Judge, T. A. (2004). Personality and transformational and transactional leadership: a meta-analysis. Journal of Applied Psychology, 89(5), 901-910. doi: https://doi.org/10.1037/0021-9010.89.5.901 
Brown, M. E., \& Trevino, L. K. (2006). Ethical leadership: A review and future directions. The Leadership Quarterly, 17(6), 595-616.

doi: https://doi.org/10.1016/j.leaqua.2006.10.004

Burgelman, R. A. (1983). Corporate entrepreneurship and strategic management: Insights from a process study. Management Science, 29(12), 1349-1364.

doi: https://doi.org/10.1287/mnsc.29.12.1349

Chen, C. Y., \& Li, C. I. (2013). Assessing the spiritual leadership effectiveness: The contribution of follower's self-concept and preliminary tests for moderation of culture and managerial position. The Leadership Quarterly, 24(1), 240-255.

doi: https://doi.org/10.1016/j.leaqua.2012.11.004

Chen, C. Y., \& Yang, C. F. (2012). The impact of spiritual leadership on organizational citizenship behavior: A multi-sample analysis. Journal of Business Ethics, 105(1), 107-114. doi: https://doi.org/10.1007/s10551-011-0953-3

Churchill, N. C. (1992). Research issues in entrepreneurship. In D. L. Sexton, \& J. D. Kasarda (Eds.), The state of the art of entrepreneurship. PWS-KENT.

Conger, J. A., \& Kanungo, R. N. (1988). The empowerment process: Integrating theory and practice. Academy of Management Review, 13(3), 471-482.

doi: https://doi.org/10.5465/amr.1988.4306983

Conger, J. A., \& Kanungo, R. N. (1998). Charismatic leadership in organizations. Sage Publications.

Covin, J. G., \& Slevin, D. P. (1991). A conceptual model of entrepreneurship as firm behavior. Entrepreneurship Theory and Practice, 16(1), 7-26.

doi: https://doi.org/10.1177/104225879101600102

Crossman, J. (2010). Conceptualising spiritual leadership in secular organizational contexts and its relation to transformational, servant and environmental leadership. Leadership $\mathcal{E}$ Organization Development Journal, 31(7), 596-608.

doi: https://doi.org/10.1108/01437731011079646

Damanpour, F. (1991). Organizational innovation: A meta-analysis of effects of determinants and moderators. Academy of Management Journal, 34(3), 555-590.

doi: https://doi.org/10.2307/256406

Day, D. V. (2000). Leadership development: A review in context. The Leadership Quarterly, 11(4), 581-613. doi: https://doi.org/10.1016/S1048-9843(00)00061-8

Deci, E. L., \& Ryan, R. M. (1991). Amotivational approach to self: Integration in personality. In R. A. Dienstbier (Ed.), Current theory and research in motivation (Vol. 38). University of Nebraska Press.

Deci, E. L., \& Ryan, R. M. (2000). The" what" and" why" of goal pursuits: Human needs and the self-determination of behavior. Psychological Inquiry, 11(4), 227-268. doi: https://doi.org/10.1207/S15327965PLI1104_01

Dent, E. B., Higgins, M. E., \& Wharff, D. M. (2005). Spirituality and leadership: An empirical review of definitions, distinctions, and embedded assumptions. The Leadership Quarterly, 16(5), 625-653. doi: https://doi.org/10.1016/j.leaqua.2005.07.002 
Depree, M. (1993). Leadership jazz: the art of conducting business through leadership, followship, teamwork, touch, voice. Dell.

Egel, E., \& Fry, L. W. (2017). Spiritual leadership as a model for Islamic leadership.Âă Public Integrity, 19(1), 77-95.

doi: https://doi.org/10.1080/10999922.2016.1200411

Elenkov, D. S., Judge, W., \& Wright, P. (2005). Strategic leadership and executive innovation influence: An international multi-cluster comparative study. Strategic Management Journal, 26(7), 665-682. doi: https://doi.org/10.1002/smj.469

Erturk, A. (2012). Linking psychological empowerment to innovation capability: Investigating the moderating effect of supervisory trust. International Journal of Business and Social Science, 3(14), 153-165.

Eyal, O., \& Kark, R. (2004). How do transformational leaders transform organizations? A study of the relationship between leadership and entrepreneurship. Leadership and Policy in Schools, 3(3), 211-235. doi: https://doi.org/10.1080/15700760490503715

Forrester, R. (2000). Empowerment: Rejuvenating a potent idea. Academy of Management Perspectives, 14(3), 67-80. doi: https://doi.org/10.5465/ame.2000.4468067

Fry, L. W. (2003). Toward a theory of spiritual leadership. The Leadership Quarterly, 14(6), 693-727. doi: https://doi.org/10.1016/j.leaqua.2003.09.001

Fry, L. W. (2005). Toward a theory of ethical and spiritual wellbeing, and corporate social responsibility through spiritual leadership. In R. A. Giacalone, \& C. L. Jurkiewicz, (Eds.), Positive psychology in business ethics and corporate responsibility. Information Age.

Fry, L. W. (2008). Spiritual leadership: State-of-the-art and future directions for theory, research, and practice. In spirituality in business. Palgrave Macmillan. doi: https://doi.org/10.1057/9780230611887_7

Fry, L. W., Hannah, S. T., Noel, M., \& Walumbwa, F. O. (2011). RETRACTED: Impact of spiritual leadership on unit performance. Elsevier.

doi: https://doi.org/10.1016/j.leaqua.2011.02.002

Fry, L. W., Matherly, L. L., \& Ouimet, J. R. (2010). The spiritual leadership balanced scorecard business model: The case of the Cordon Bleu-Tomasso Corporation. Journal of Management, Spirituality and Religion, 7(4), 283-314.

doi: https://doi.org/10.1080/14766086.2010.524983

Fry, L. W., Vitucci, S., \& Cedillo, M. (2005). Spiritual leadership and army transformation: Theory, measurement, and establishing a baseline. The Leadership Quarterly, 16(5), 835-862. doi: https://doi.org/10.1016/j.leaqua.2005.07.012

Fry, L., Hannah, S., Noel, M., \& Walumbwa, F. (2011). Impact of spiritual leadership on unit performance. The Leadership Quarterly, 22, 259-270.

doi: https://doi.org/10.1016/j.leaqua.2011.02.002

Gawke, J. C., Gorgievski, M. J., \& Bakker, A. B. (2017). Employee intrapreneurship and work engagement: A latent change score approach. Journal of Vocational Behavior, 100, 88-100. doi: https://doi.org/10.1016/j.jvb.2017.03.002 
Gilson, L. L., \& Shalley, C. E. (2004). A little creativity goes a long way: An examination of teams' engagement in creative processes. Journal of Management, 30(4), 453-470. doi: https://doi.org/10.1016/j.jm.2003.07.001

Gumusluoglu, L., \& Ilsev, A. (2009). Transformational leadership, creativity, and organizational innovation. Journal of Business Research, 62(4), 461-473.

doi: https://doi.org/10.1016/j.jbusres.2007.07.032

Gumusay, A. A. (2015). Entrepreneurship from an Islamic perspective. Journal of Business Ethics, 130(1), 199-208. doi: https://doi.org/10.1007/s10551-014-2223-7

Hackman, J. R. (1980). Work redesign and motivation. Professional Psychology, 11(3), 445-455. doi: https://doi.org/10.1037/0735-7028.11.3.445

Hair, J. F., Black, W. C., Babin, B. J., Anderson, R. E., \& Tatham, R. L. (2006). Multivariate data analysis (Vol. 6). Pearson Prentice Hall.

Hair, J. F., Sarstedt, M., Ringle, C. M., \& Mena, J. A. (2012). An assessment of the use of partial least squares structural equation modeling in marketing research. Journal of the Academy of Marketing Science, 40(3), 414-433. doi: https://doi.org/10.1007/s11747-011-0261-6

Hempel, P. S., Zhang, Z. X., \& Han, Y. (2012). Team empowerment and the organizational context: Decentralization and the contrasting effects of formalization. Journal of Management, 38(2), 475-501. doi: https://doi.org/10.1177/0149206309342891

Hofstede, G. (1984). Culture's consequences: International differences in work-related values (Vol. 5): sage.

Hoppe, S. L. (2005). Spirituality and leadership. New Directions for Teaching and Learning, 104, 83-92. doi: https://doi.org/10.1002/tl.217

Hornsby, J. S., Kuratko, D. F., \& Zahra, S. A. (2002). Middle managers' perception of the internal environment for corporate entrepreneurship: Assessing a measurement scale. Journal of Business Venturing, 17(3), 253-273.

doi: https://doi.org/10.1016/S0883-9026(00)00059-8

Howell, J. M., \& Higgins, C. A. (1990). Champions of technological innovation. Administrative Science Quarterly, 35(2), 317-341. doi: https://doi.org/10.2307/2393393

Jabri, M. M. (1991). The development of conceptually independent subscales in the measurement of modes of problem solving. Educational and Psychological Measurement, 51(4), 975-983. doi: https://doi.org/10.1177/001316449105100417

Jung, D. I., \& Avolio, B. J. (2000). Opening the black box: An experimental investigation of the mediating effects of trust and value congruence on transformational and transactional leadership. Journal of Organizational Behavior, 21(8), 949-964.

doi: https://doi.org/10.1002/1099-1379(200012)21:8<949::AID-JOB64>3.0.CO;2-F

Jung, D. I., Chow, C., \& Wu, A. (2003). The role of transformational leadership in enhancing organizational innovation: Hypotheses and some preliminary findings. The Leadership Quarterly, 14(4-5), 525-544. doi: https://doi.org/10.1016/S1048-9843(03)00050-X

Kanter, R. M. (1984). Change masters. Simon and Schuster.

Kayed, R. N., \& Hassan, K. (2010). Islamic entrepreneurship. Routledge. 
Khan, H. A. (2018). Globalization and leadership challenges. In Globalization and the challenges of public administration. Springer.

doi: https://doi.org/10.1007/978-3-319-69587-7_4

Klein, W. M., \& Kunda, Z. (1994). Exaggerated self-assessments and the preference for controllable risks. Organizational Behavior and Human Decision Processes, 59(3), 410-427. doi: https://doi.org/10.1006/obhd.1994.1067

Koh, W. L., Steers, R. M., \& Terborg, J. R. (1995). The effects of transformational leadership on teacher attitudes and student performance in Singapore. Journal of Organizational Behavior, 16(4), 319-333. doi: https://doi.org/10.1002/job.4030160404

Krueger Jr, N., \& Dickson, P. R. (1994). How believing in ourselves increases risk taking: Perceived self-efficacy and opportunity recognition. Decision Sciences, 25(3), 385-400. doi: https://doi.org/10.1111/j.1540-5915.1994.tb01849.x

Kuratko, D. F., Ireland, R. D., Covin, J. G., \& Hornsby, J. S. (2005). A model of middlelevel managers' entrepreneurial behavior. Entrepreneurship Theory and Practice, 29(6), 699-716. doi: https://doi.org/10.1111/j.1540-6520.2005.00104.x

Latham, J. R. (2014). Leadership for quality and innovation: Challenges, theories, and a framework for future research. Quality Management Journal, 21(1), 11-15. doi: https://doi.org/10.1080/10686967.2014.11918372

Lawler, E. E., Mohrman, S. A., \& Benson, G. (2001). Organizing for high performance: Employee involvement, TQM, reengineering, and knowledge management in the Fortune 1000. Jossey Bass.

Lord, R. G., \& Brown, D. J. (2001). Leadership, values, and subordinate self-concepts. The Leadership Quarterly, 12(2), 133-152. doi: https://doi.org/10.1016/S1048-9843(01)00072-8

Lean, E. R. (2012). The construct development of spiritual leadership (Ph.D. dissertation). University of Arkansas, SA.

Lumpkin, G. T., \& Dess, G. G. (1996). Clarifying the entrepreneurial orientation construct and linking it to performance. Academy of Management Review, 21(1), 135-172. doi: https://doi.org/10.2307/258632

Macneil, I. R. (1985). Relational contract: What we do and do not know. Wisconsin Law Review, 483-525.

Mahmood, A. (2006). Psychology and Shia Muslims. In E. T. Dowd, \& S. R. Nielson (Eds.), The psychologies in religion: Working with the religious client (pp. 237-252). Springer.

Markow, F., \& Klenke, K. (2005). The effects of personal meaning and calling on organizational commitment: An empirical investigation of spiritual leadership. International Journal of Organizational Analysis, 13(1), 8-27. doi: https://doi.org/10.1108/eb028995

Mathieu, J. E., Gilson, L. L., \& Ruddy, T. M. (2006). Empowerment and team effectiveness: an empirical test of an integrated model. Journal of Applied Psychology, 91(1), 97-108. doi: https://doi.org/10.1037/0021-9010.91.1.97

Maynard, M. T., Gilson, L. L., \& Mathieu, J. E. (2012). Empowerment-fad or fab? A multilevel review of the past two decades of research. Journal of Management, 38(4), 1231-1281. doi: https://doi.org/10.1177/0149206312438773 
McCormack, K., Bronzo Ladeira, M., \& Paulo Valadares de Oliveira, M. (2008). Supply chain maturity and performance in Brazil. Supply Chain Management: An International Journal, 13(4), 272-282. doi: https://doi.org/10.1108/13598540810882161

McGill, M. E., Slocum Jr, J. W., \& Lei, D. (1992). Management practices in learning organizations. Organizational Dynamics, 21(1), 5-17. doi: https://doi.org/10.1016/0090-2616(92)90082-X

Modaff, D. P., DeWine, S., \& Butler, J. A. (2008). Organizational communication: Foundations, challenges, and misunderstandings. Pearson/Allyn \& Bacon.

Moriano, J. A., Molero, F., Topa, G., \& Mangin, J.-P. L. (2014). The influence of transformational leadership and organizational identification on intrapreneurship. International Entrepreneurship and Management Journal, 10(1), 103-119.

doi: https://doi.org/10.1007/s11365-011-0196-x

Morrison, E. W., \& Phelps, C. C. (1999). Taking charge at work: Extra role efforts to initiate workplace change. Academy of Management Journal, 42(4), 403-419. doi: https://doi.org/10.5465/257011

Morrison, E. W., \& Robinson, S. L. (1997). When employees feel betrayed: A model of how psychological contract violation develops. Academy of Management Review, 22(1), 226-256. doi: https://doi.org/10.2307/259230

Mumford, M. D., Scott, G. M., Gaddis, B., \& Strange, J. M. (2002). Leading creative people: Orchestrating expertise and relationships. The Leadership Quarterly, 13(6), 705-750. doi: https://doi.org/10.1016/S1048-9843(02)00158-3

Parker, S. K. (1998). Enhancing role breadth self-efficacy: The roles of job enrichment and other organizational interventions. Journal of Applied Psychology, 83(6), 835-852. doi: https://doi.org/10.1037/0021-9010.83.6.835

Parker, S. K., Wall, T. D., \& Jackson, P. R. (1997). "That's not my job": Developing flexible employee work orientations. Academy of Management Journal, 40(4), 899-929. doi: https://doi.org/10.5465/256952

Parker, S. K., Williams, H. M., \& Turner, N. (2006). Modeling the antecedents of proactive behavior at work. Journal of Applied Psychology, 91(3), 636-652. doi: https://doi.org/10.1037/0021-9010.91.3.636

Podsakoff, P. M., MacKenzie, S. B., Moorman, R. H., \& Fetter, R. (1990). Transformational leader behaviors and their effects on followers' trust in leader, satisfaction, and organizational citizenship behaviors. The Leadership Quarterly, 1(2), 107-142. doi: https://doi.org/10.1016/1048-9843(90)90009-7

Rauch, A., Wiklund, J., Lumpkin, G. T., \& Frese, M. (2009). Entrepreneurial orientation and business performance: An assessment of past research and suggestions for the future. Entrepreneurship Theory and Practice, 33(3), 761-787. doi: https://doi.org/10.1111/j.1540-6520.2009.00308.x

Robinson, S. L., Kraatz, M. S., \& Rousseau, D. M. (1994). Changing obligations and the psychological contract: A longitudinal study. Academy of Management Journal, 37(1), 137-152. doi: https://doi.org/10.2307/256773 
Rousseau, D. M., \& McLean Parks, J. (1993). The contracts of individuals and organizations. Research in Organizational Behavior, 15, 1-43.

Shalley, C. E., Zhou, J., \& Oldham, G. R. (2004). The effects of personal and contextual characteristics on creativity: Where should we go from here? Journal of Management, 30(6), 933-958. doi: https://doi.org/10.1016/j.jm.2004.06.007

Shamir, B. (1990). Calculations, values, and identities: The sources of collectivistic work motivation. Human Relations, 43(4), 313-332. doi: https://doi.org/10.1177/001872679004300402

Shamir, B., House, R. J., \& Arthur, M. B. (1993). The motivational effects of charismatic leadership: A self-concept based theory. Organization Science, 4(4), 577-594. doi: https://doi.org/10.1287/orsc.4.4.577

Sheldon, K. M. (1995). Creativity and self-determination in personality. Creativity Research Journal, 8(1), 25-36. doi: https://doi.org/10.1207/s15326934crj0801_3

Sitkin, S. B., \& Pablo, A. L. (1992). Reconceptualizing the determinants of risk behavior. Academy of Management Review, 17(1), 9-38. doi: https://doi.org/10.2307/258646

Sitkin, S. B., \& Weingart, L. R. (1995). Determinants of risky decision-making behavior: A test of the mediating role of risk perceptions and propensity. Academy of Management Journal, 38(6), 1573-1592. doi: https://doi.org/10.5465/256844

Sosik, J. J. (1998). Self-concept based aspects of the charismatic leader: More than meets the eye. The Leadership Quarterly, 9(4), 503-526. doi: https://doi.org/10.1016/S1048-9843(98)90013-3

Spreitzer, G. M. (1995). Psychological empowerment in the workplace: Dimensions, measurement, and validation. Academy of Management Journal, 38(5), 1442-1465. doi: https://doi.org/10.2307/256865

Spreitzer, G. M. (1996). Social structural characteristics of psychological empowerment. Academy of Management Journal, 39(2), 483-504.

doi: https://doi.org/10.2307/256789

Spreitzer, G.M. (2008). Taking Stock: A review of more than twenty years of research on empowerment at work. In C. Cooper, \& J. Barling (Eds.), Handbook of organizational behavior. Sage. doi: https://doi.org/10.4135/9781849200448.n4

Stull, M. (2005). Intrapreneurship in nonprofit organizations: Examining the factors that facilitate entrepreneurial behavior among employees. Case Western University, Cleveland, $\mathrm{OH}$.

Tajeddini, K., Martin, E., \& Ali, A. (2020). Enhancing hospitality business performance: The role of entrepreneurial orientation and networking ties in a dynamic environment. International Journal of Hospitality Management, 90, 102605. doi: https://doi.org/10.1016/j.ijhm.2020.102605

TechJuice. (2015). 20 reasons why Pakistan's technology industry is much more than a fake degree scam.

Retrieved from: https://www.techjuice.pk/pakistan-technology-achievements/

Thomas, K. W., \& Velthouse, B. A. (1990). Cognitive elements of empowerment: An "interpretive" model of intrinsic task motivation. Academy of Management Review, 15(4), 666-681. doi: https://doi.org/10.2307/258687 
Tierney, P., Farmer, S. M., \& Graen, G. B. (1999). An examination of leadership and employee creativity: The relevance of traits and relationships. Personnel Psychology, 52(3), 591-620. doi: https://doi.org/10.1111/j.1744-6570.1999.tb00173.x

Toor, S. (2011). An Islamic leadership theory: Exploring the extra dimensions. In K. Ahmad, R. Islam, \& Y. Ismail (Eds.), Issues in Islamic management: Theories and practices (pp. 324-339). IIUM Press.

Utman, C. H. (1997). Performance effects of motivational state: A meta-analysis. Personality and Social Psychology Review, 1(2), 170-182.

doi: https://doi.org/10.1207/s15327957pspr0102_4

Wagner III, J. A. (1994). Participation's effects on performance and satisfaction: A reconsideration of research evidence. Academy of Management Review, 19(2), 312-330. doi: https://doi.org/10.2307/258707

Wang, M., Guo, T., Ni, Y., Shang, S., \& Tang, Z. (2019). The effect of spiritual leadership on employee effectiveness: An intrinsic motivation perspective. Frontiers in Psychology, 9, 26-27. doi: https://doi.org/10.3389/fpsyg.2018.02627

Wallace, J. C., Johnson, P. D., Mathe, K., \& Paul, J. (2011). Structural and psychological empowerment climates, performance, and the moderating role of shared felt accountability: A managerial perspective. Journal of Applied Psychology, 96(4), 840. doi: https://doi.org/10.1037/a0022227

Zhang, X., \& Bartol, K. M. (2010). Linking empowering leadership and employee creativity: The influence of psychological empowerment, intrinsic motivation, and creative process engagement. Academy of Management Journal, 53(1), 107-128.

doi: https://doi.org/10.5465/amj.2010.48037118 